\title{
HISTORICAL EARTHEN WALLS: FROM KNOWLEDGE TO CONSCIOUS CONSERVATION
}

\author{
D. Pittaluga ${ }^{1, *}$, A. Di Rocco ${ }^{1}$, C. Casagrande ${ }^{1}$, S. Guerinoni ${ }^{1}$, G. Pellegri ${ }^{1}$ \\ ${ }^{1}$ DAD, Università degli Studi di Genova, Italy - (daniela.pittaluga, pellegri)@arch.unige.it, (alessia.dirocco94, clary.casa, \\ silviaguerinoni)@gmail.com,
}

Comission II - WG/8

KEY WORDS: Conservation, Earthen walls, Knowledge, Historical restorations, brick-faced rammed earth

\begin{abstract}
:
Centuries-old earthen masonry presenting various stages of degradation, earthen walls that have been restored several times: these are the archeological phases of the city walls of Mascarell, on the Spanish Mediterranean coast. Founded in the first half of the 13th century, this town is the only complex in Castellon Province that preserves all its ancient walls, which were built entirely by means of the brick-faced rammed-earth technique (clay with bricks and lime). This article reports the first results of a research project conducted on the multiple information available on these artifacts: bibliographic, archival and iconographic sources and the results of direct material analysis, stratigraphic analysis and archeological analysis. The situation is complex, as these walls have undergone a long sequence of transformations, including interventions carried out since the 18th century and multiple restorations in the period 1942-2015. The research developed and refined architecture archeology tools in order to analyze the rammed-earth techniques adopted during restoration work (similar but not identical to the historical technique), to characterize the materials used in restoration, to evaluate their resistance to degradation over the years, to define a sort of 'critical evolutionary line' of rammed-earth restoration, and to conduct a cross-sectional study of this building technique from the Middle Ages to the present. Finally, we drafted some guidelines for future interventions for conservation and enhancement.
\end{abstract}

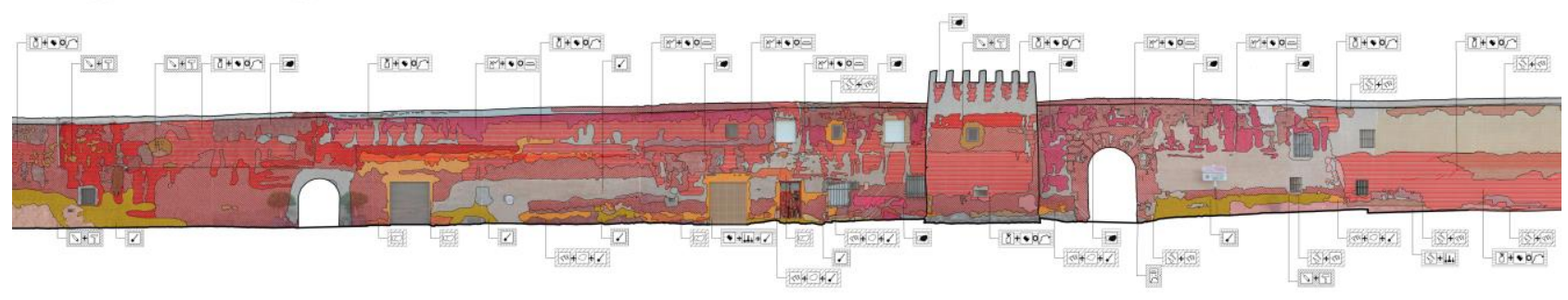

Figure 1. Mascarell city walls, SE section. Thematic map of restoration interventions.

\section{INTRODUCTION}

This article explains a research methodology that compares the data derived from direct and indirect sources in order to provide indications for restoration projects that conserve both the materials originally used and the intangible cultural heritage.

The modular walling technique called tapia, i.e. rammed earth, has been used for millennia throughout the Iberian Peninsula, both in monumental and domestic architecture. Wet earth - a blend of clay, lime, sand and gravel - is carefully pressed manually. This earth mixture is enriched with pieces of cane, layers of straw, mortars and other binders to promote adhesion, strengthen the structure and protect against mechanical actions and rising capillary humidity. Under pressure, the binders emerge to the surface and create a smooth, uniform layer that protects against atmospheric phenomena (Cristini, Ruiz Checa, 2009a and 2009b). Baked bricks, stones, adobe and other reinforcement elements are carefully added (Font, Hidalgo, 1990) and (Galarza Tortajada, 1996). Several varieties of rammed-earth construction can be identified. In some cases, stones (or stones and lime mortar or plaster mortar) are inserted inside the wall to increase its strength. In other cases, stone or brick pillars may be used to reinforce the cantonal or opening jambs. A stone base is sometimes present as a protection against rising damp. In the Valencia region, a special variant of rammed earth is used, in which some regular horizontal courses of bricks are incorporated into the earthen wall. The horizontal distance between one brick and another varies greatly according to the area and the historical period (Cristini et al., 2015). Several studies have been carried out on this technique and the reasons for its widespread diffusion; a particularly accredited hypothesis is that bricks provide greater cohesion between the various layers of the wall (Martella, 2015).

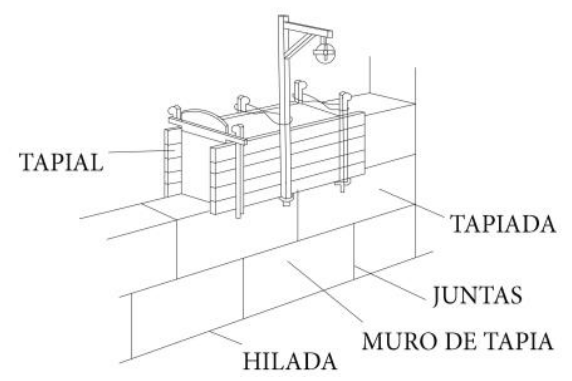

Figure 2. 'Tapia' nomenclature, redrawn by C.A.Casagrande.

\footnotetext{
* Corresponding author
} 
Mascarell, a small village of 200 inhabitants in Castéllon province, was declared an asset of cultural interest ('Bien de Intérêt Cultural') in 1995. Its center is mainly medieval, but the walls date back to the 16th century. Erected after the reconquest of Valencia by King Jaime I, it once belonged, together with Moncofar and Villavieja, to the barony and marquisate of Nules and became a district of the latter town in the late 19th century. Mascarell is the only complex in the province of Castéllon that entirely preserves its ancient rammed earth walls. The walls have a total perimeter of 620 m. (Taberner Pastor, 2012).

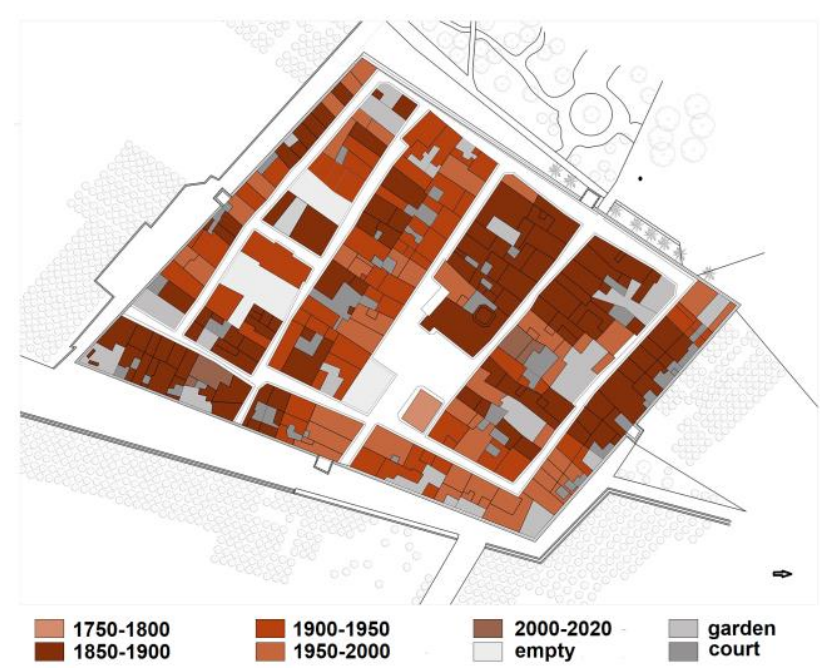

Figure 3. Mascarell map of modifications after original walls construction.

\section{AIMS OF THE STUDY}

One of our objectives was to study the walls both in their current state, which includes part of the 16th century walls, and the subsequent additions and restorations that took place between the 20th and 21st centuries. The challenge was to demonstrate the importance of the different traces, even the most minute ones, to recount the history of this city through those signs, and to design a possible restoration that would preserve the memory of all of them. This involved adopting a method of working that would allow us to capture and enhance all the specific features of a multi-layered construction (Casagrande, Di Rocco, Guerinoni, 2019).

\section{METHOD OF THE STUDY}

What methodological problems did this research pose? First, the characteristics of Mascarell site: this is one of the few urban centers in the province that have completely preserved their earthen perimeter walls. Second, these ancient walls have undergone various transformations and restorations, which meant that diversified readings and analysis tools and innovative strategies were needed. Third, the challenge of providing a broad and diversified program of cultural accessibility. The method applied consisted of the following phases:

- Analysis of indirect sources (bibliographic, cartographic, iconographic, archive documents, both published and unpublished).

- Analysis of direct sources (the building itself, materials, surfaces, traces of processes and transformations (Pittaluga, 2009a): survey (sketching fundamental geometries, but also the signs and irregularities that could be linked to interventions dating from different eras); analysis of the materials; analysis of degradation; architecture archaeological analysis (applied to results of previous phases).

- Comparison between the different analyses (the key phase).

- Guidelines for restoration and enhancement (based on all previous phases).

In detail, the research started with the study of indirect sources, a complete survey of the walls and an overall stratigraphic analysis. Subsequently, some critical areas were identified, from which micro-samples of materials were taken. These samples were analyzed in the laboratory, in order to answer questions such as: areas of recent restoration that show evident degradation phenomena characterized by different materials or by different processes? Did all the best-preserved coeval samples use the same mix of materials? If so, were the processes different? Only after answering all these questions did we possess all the elements to summarize the observations collected and thus define guidelines for the conservation and enhancement project.

\section{RESULTS OF RESEARCH INTO INDIRECT SOURCES}

With regard to the original construction of these walls, we collected and reorganized documents obtained from previous studies. According to archival documents, construction of the walls began in 1553 and ended in 1555. The work was commissioned by Francisco Juan de Sentacreu, the procurator of Maria de Cardona Countess of Oliva, and Pere Just, the mayor and procurator of the village and the University of Mascarell; the master builders were Pedro Climent and Jacobi Garces. Pedro Climent was an authoritative member of the workers' guild; he was a great expert in the tapia technique as he had already carried out prestigious works. Juame Lombart and Joan Forner also worked on the project. Three Camino family stonemasons, Pedro, Joan and Sancho, from Biscay, who had had important previous experience as architects in various works in the province of Castellon, were part of the team. Frequently mentioned in the document, and of clear fame, are Joan of Alicante, father and son; both had worked on important constructions in the territory of Valencia: fortifications, a general hospital, the parish church of Algemesi, and the school of Santo Domingo de Orihuela. The contract for the construction works describes in detail the materials required and the dimensions and specifications of the walls (Casagrande, Di Rocco, Guerinoni, 2019). Over the years, the walls of Mascarell suffered several collapses and conservation problems. To better understand these issues, we conducted an in-depth research of the restoration works carried out in the 20th and 21 st centuries, based on bibliographic and archival sources ${ }^{1}$, and we identified eight different restoration phases: 1942, 1979, 1987, 1988, 1989-'90, 2000, 2008-'10, 2015. A summary of this research work is given below, limited to the interventions strictly connected to the walls.

\footnotetext{
Archive "Regiones Devastadas"-Municipio de Nules, "Restauracion Murallas Mascarell", June 1979, 11/11/1987, Nules Archive of Castellon, Planos de l'arquitecto Municipal", Nules, avril 1989 Archive of Castellon, Doc.6-apr-1990, Doc.28/3/1996, Doc. "Modificado de Proyecto de consolidacion, restauracion y puesta en valor del lienzo de las murallas de Mascarell" Castellon Archive, 2010, "Consolidation, restoration and enhancement of the SW walls of Mascarell, phase 2" by Francisco Taberner Archive 2015; Cf. Galarza Tortajada, 2012
} 


\section{RESULTS OF RESEARCH OF DIRECT SOURCES}

The analysis of indirect sources conducted in the initial phase of this research uncovered written records of the ancient origin of the walls and of several modifications: both those of the 16th19th centuries and the restoration work carried out in the 20th 21 st centuries. We felt, however, that these written traces needed to be verified through examination of the real artifact, in order to answer such questions as: Is it true that these walls are so ancient, when they have quite similar characteristics to walls dating from other periods in other cities in the Castellon de la Plana area? Were the restoration plans that we found in the archives really executed or did they remain at the design stage? Where are the traces of these interventions on the real artifact today? Is it possible to identify other transformations, besides those mentioned by indirect sources? How effective has recent restoration work been? Is it possible to remedy current situations of decay without canceling the traces of past modifications, even those that were least effective? A detailed archeological analysis was undertaken in order to answer these questions.

\subsection{Survey of the walls}

The first step in this analysis was to make a complete survey of the walls of Mascarell by applying two different techniques to the entire perimeter $(620 \mathrm{~m}$ in length) and integrating the results yielded by each technique: a longimetric survey (i.e. using only linear measurements, no angles) and a photogrammetric survey (with straightening). The longimetric method provided a basic set of measurements of all the walls; a detailed longimetric survey was carried out in zones of special interest, such as the towers and the NE elevation. The photogrammetric survey was performed on all external walls, no details excluded, by using the 'simplified' 2D (bi-dimensional) method, with RDF software. The abundance of measurements and integration of longimetric data allowed us to minimize the quantity of "nonstraightened' areas. As a result, a very large number of accurate, straightened images of the wall were obtained, which provided a large amount of information on the materials and on the state of degradation of the artifact. The photo-straightened and digitized elevations were the basis for material maps, maps of degradation phenomena, stratigraphic maps and maps of conservative interventions to be carried out in the near future.

\subsection{The archeology of architecture in understanding the walls}

"The critical understanding of architectural texts (i.e. architecture archeology) gives us a partial answer to the problem of conservation. In the field of historical architecture, the task of archeologists must be exemplary. To them, architectural elements and their configuration are not 'values to confirm or deny'; rather, they are a system of material signs (Torsello, 2006). For a long time, it was thought that knowing meant superimposing a pattern on reality, rather than learning from it" (Ginzburg, 1998).

Today we have the need and also the opportunity, to develop tools that enable us to look at reality critically and to learn from it. Thus, in the conservation sector, the archeology of architecture imposes on the architect a different way to find a synthesis, an approach that involves analyzing construction practices, empirical knowledge and the traditional use of materials. This orientation by no means excludes the use of analytical methods and laboratory experiments; rather, these techniques are complementary to other tools, which could be regarded as borrowed from the 'new historiography' (Della Torre, Pracchi, 2006) and (Boato, Pittaluga 2000) and (Pittaluga, 2009a). The architect-archeologist's point of view has been present since the birth of restoration in a modern sense. Formerly, however, it did not have the strength that it would subsequently acquire with the archeology of architecture. In the practice of restoration between the 19th and 20th centuries, the emphasis on archeology was simply the most clearly recognizable version of philology. At that time, it was impossible to conceive of the idea which later became fundamental to the archeology of architecture: the idea of a work as a continuous process, in which even degradation plays a significant part in the narration and explanation of its history (Della Torre, Pracchi, 2006).

5.2.1 Stratigraphic analysis of the walls: The stratigraphic analysis was carried out along all four external faces. Today, these areas are visible, with the exception of very few parts that are hidden by dense vegetation growing on the walls themselves. The internal facades, by contrast, are more difficult to see, as most of them are hidden by the buildings that have been erected over the years. We also had to face several other difficulties: the points of contact between different stratigraphic units were sometimes inaccessible, and it was not possible to discern the stratigraphic relationships among them; another problem was the large number of data collected and analyzed.

5.2.2 The difficulty of finding elements for dating earthworks: Finding dating elements in earthen walls is not easy. Indeed, the solution often adopted is to search for generically 'long-lasting elements' (Boato, Pittaluga, 2000); moreover, an earthen wall has fewer elements that can be used for dating (Pittaluga, 2012) and (Pittaluga, Pagella, 2015). Some previous studies have attempted to create 'chronotypologies' of the different building techniques, and have obtained comforting results (Mileto, Vegas, Cristini, 2012) and (Mileto et al., 2015). Other elements that can be used to identify chronological phases are found in the mixtures of the materials used, in the analysis of the traces of the molds and in the study of other materials, such as brick, stone courses etc. (Pittaluga, 2009b) and (Pittaluga, Fratini, 2019) In the present study, this approach sometimes helped us to identify the different phases of construction and small modifications of the walls. As regards the identification of the restoration of the 20th and 21 st centuries, dating elements enabled us to confirm the veracity of indirect sources ${ }^{2}$.

5.2.3 Chronotypological analyses: Unlike the various studies $^{3}$ that focus on 'type', chronotypology takes on a specific connotation (Ferrando Cabona, Mannoni, Pagella, 1989). In the archeological field, the notion of 'type' is linked to a classification procedure which allows us to objectively recognize, in a sufficiently large set of comparable 'individuals', a certain number of common and co-present characteristics. Unlike the taxonomies of the natural sciences, which are based on genetic relationships, the classification of artifacts rests on cultural relationships. Affinities depend on numerous factors, including: at the economical level, mass production; at the social level, realism, imitation and fashion; at a technical level, production techniques based on empirical knowledge and on the transmission of knowledge in the workshop and on site. In any case, for the purposes of archeological investigation and, in particular, of dating, it is essential that the artifacts subjected to typological investigation be homogeneous, i.e. the result of a unitary constructive intervention. For this reason, it is difficult to develop typologies

2 Cf. (Pittaluga, Fratini, 2019), papers by K.R.Chaham, N.Gamrani, M. Ibnoussina, D.Abbou, N.A.Mahindad.

3 Cf. (Quatremère, rp. 1985) and (Moneo, 1978) and (Muratori, 1984) and (Rogers,1985) and (Caniggia, 1996). 
on a building scale, since buildings are normally subject to continual transformation, while observation of the basic elements that are identifiable in the units or in the stratigraphic sub-units offers greater guarantees of success. A crucial node in this procedure is the definition of the specific time bands of each type, which must necessarily be linked to factors that are external to the typology: epigraphs and documentation, and also dates derived by means of other archeological instruments, provided that they are obtained in total autonomy. Sometimes a relative sequence between the different types can be established with the help of stratigraphic analyses. In this way, a relative chronotypology will be obtained. In any case, it is necessary to refrain from 'filling in the blanks' with interpolated data, in order to avoid misinterpretations. Chronotypology, is therefore a direct, non-destructive method of dating that is applicable to categories of real movable artifacts (ceramics...), to architectural elements (portals, balustrades, masonry techniques...) belonging to a unitary geographical area, from the social, economic and cultural point of view. It is based on direct observation and on the detection of morphological and technical aspects of the artifact, with the aim of defining its belonging (or not) to the 'chronotype' (Pittaluga, 2009a). The cronotype is the group of artifacts that have the same characteristics in terms of materials, techniques, shapes and measurements within codifiable tolerances and with a fairly limited duration in a given territory. Dating error and the validity of the results depend on the level of in-depth analysis of the chronotype (number of cases and detailed analysis) and on the existence of recognizable variations in a limited time-span: in some cases, the imprecision of dating could be ten years, in others a century. Some specific issues have to be considered in chronotypological dating, in order to achieve valuable results. There may be small, involuntary variations due to manufacturing errors and imperfections. Delays (i.e. persistence of a chronotype for a longer period) may be linked to particular socio-economic situations (e.g. rural/urban area). Moreover, an older chronotype may be revived at a later time, onvoluntary variations may be implemented in individual works as a personal expression of the operator. The method of chronotyping was developed by ISCUM (Institute of History of Material Culture). In the specific case of the study of the walls of Mascarell, the chronotype analysis mainly focused on the building techniques.

\subsection{The materials of the walls}

5.3.1 Original 1553 wall - materials, construction techniques, decay: "Today, the configuration of Mascarell's walls is the same as that described in the original contract... The greatest interest arising from the contract document primarily lies in two issues: first, the precise dating of the work; second, the description of the technique used to build the wall, which was none other than the Valencian rammed earth wall or tapia: tapia made of 'terra y crosta' (earth and coating), consisting of half a brick on each side, interior and exterior, of the wall" (Taberner 2012, 239-240).

The 1553 walls, with a linear extension of $620 \mathrm{~m}$, are composed as follows, as described in the documents and as detected by the archeological analysis of the elevation: A- Foundations, 6 palms wide $(125 \mathrm{~cm})$; the excavation is filled with limecrete (lime and stone). In direct analysis, it was not possible to observe the foundations, except in very limited portions. B- Stone masonry immediately above the foundations, 2 feet high and 5 palms wide $(104 \mathrm{~cm}, 1$ palm $=20.873 \mathrm{~cm})$. This part of the masonry does not consist of rammed earth, but is composed mainly of stones and airhardening lime mortar. This part of the wall underwent frequent interventions and repairs over time, and is therefore sometimes difficult to 'read'. C- Masonry composed of rammed earth, described in the document as 'terra y crosta' (earth and coating). The document provides the specifications of the 'crust': the 'crust' consists of half-brick elements inserted on each side of the wall: internal and external surfaces. Traces of the wooden molds used are among the signs that characterize this construction method: 5 horizontal stripes on the wall, left by the mold of $3.70 \mathrm{~m} \times 1.15 \mathrm{~m}$; these signs are almost constant in all the prospects. Small variations of the masonry technique are to be seen in this section of the wall, even in parts that are coeval, for example the distances between bricks, or the regularity of brick dimensions. Given the extension of the walls, it is possible that more than one team of bricklayers worked simultaneously; this could explain the presence of these small differences. There are no major chromatic variations; this could be due to a single supply of clay for the whole project. There are, however, minor chromatic variations due to the habit of adding lime to the earth; this lime is located at the bottom of the block under construction, inside the mold; as the earth is beaten, some of the lime tends to spread to the sides of the rammed earth block. Several stratigraphic units have been identified, all dating back to 16th century, with minor variations in the tapia technique, probably related to different workers skills (Table 1).

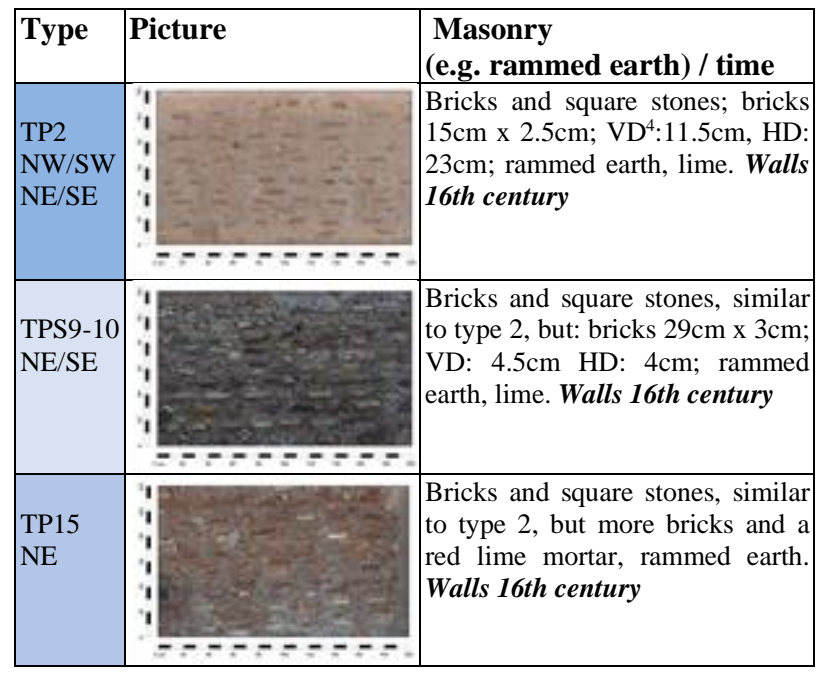

Table 1. Masonry techniques table: the dimensional values are arithmetic average of the values measured on site.

D- The finish on the coping. Taberner reports that "The finish of the wall consists of limecrete" (Taberner Pastor 2012, 239), which he defines as "lime and stone". The coping of the wall is shaped in such a way as to allow the water to run off. While its internal structure consists of stones, its outer surface is covered with lime, earth and brick dust plaster. Bricks and limecrete are visible on all four external faces of the rammed-earth walls of 1553-1555, with small variations from one to another. The face on which it is (most visible is the south-east one (59\% of the materials visible in the same prospect); the face on which they appear least is the north-east elevation (33\% of visible materials). This is due in part to conservation problems and in part to changes or demolition/damage that the walls have undergone. Note on the materials: fragments of brick dust additive were detected in the composition of the rammed earth (s.n.2) and of the mortar coating above (s.n.10); this direct observation on samples is consistent with indirect bibliographic and archival sources. If these data are confirmed by other samplings, this could be a sign of a precise choice made in the 16th century, but not replicated in the subsequent interventions, in order to make the entire masonry resistant to water. Indeed, brick dust has good water-resistant properties, which are transferred to the mixture into which it is incorporated.

\footnotetext{
${ }^{4} \mathrm{VD}=$ vertical distance, $\mathrm{HD}=$ horizontal distance.
} 
5.3.2 Restoration work: Restoration work carried out in the 20th and 21 st centuries involved:

A- Foundations: no major transformation or restoration of the foundations.

B- Masonry immediately above the foundations, 2 feet high and 5 palms thick: apparently, no major restorations; however, it is difficult to inspect these portions of masonry as they are concealed by restorations and other surface interventions carried out over time.

C- Rammed earth masonry. Some sections were damaged by degradation and artificial destructive events. Several repairs and restorations have been carried out over time. In many cases, restorations used different materials and construction techniques from the original ones (interventions of 1942 and 1979 by Francisco Segarra), while in the most recent restorations, materials and techniques similar to the historical ones were used (2010-2015). In all cases, the thickness and height of the masonry - i.e. the dimensions of the original 16 th century walls - were maintained. 1942- Reconstructions used stone pebbles according to the technique called mamposteria: specifically, stone pebbles simply collected from the ground or, at most, fragmented. For masonry reconstruction, these stone pebbles were incorporated into a large pouring of air-hardening lime mortar in molds. Consequently, the visual prospect of this masonry is that of a large surface of mortar with stone elements emerging at different points. The dimensions of the mold are also specific to Mascarell, and very similar to those used in the 16 th century in rammed-earth wall construction. Consequently, the signs visible on the surface are similar to those of the original masonry. This restoration involved the NW and SE faces. 1979 - In the restorations carried out by Francisco Segarra, hollow bricks, concrete with lime and cement mortar are used. In the logic of this restoration, only the geometric lines of the walls (height, thickness) are re-proposed. Moreover, the coating is deliberately not laid flush with the portions of the existing masonry, but is slightly raised in order to make the restored part evident. In some ways, therefore, this was a sign of respect for the authenticity of the material, even though putting incompatible materials together (lime and cement) leads to serious consequences in terms of conservation. 2010-2015 Taberner's intervention adopted the rammed earth construction technique and tried to use similar materials; this is the only case of this type of choice for the restoration of Mascarell's walls. Rammed earth masonry is described as 'terra y crosta' (earth and coating) in this document. This restoration shows features similar to those of the original walls, i.e. 5 courses of bricks in a $3.70 \times 1.15$ space, the dimension of the original wooden mold. Concerning the choice of the clay, the designer Paco Taberner, whom we interviewed during this research, provided all the details: there was rigorous respect for the 16th century tradition. Restored rammed earth shows small color variations, which are not due to artificial dyes.

D- special processing on the coping of the walls. The coping of the walls, even when it has been restored, maintains the classic cambered shape, which allows rainwater to run off. In this part, however, in all the restorations, there was a greater presence of cement mortars.

\begin{tabular}{|l|l|}
\hline Restoration works details \\
\hline 1942 & $\begin{array}{l}\text { The wedges of Valencia portal were replaced; part of the wall } \\
\text { nearby had been replaced with a masonry using very dense } \\
\text { rounded stones (mamposteria). The formwork dimensions are } \\
\text { identical to the ones used in 16th century for the tapia. }\end{array}$ \\
\hline
\end{tabular}

1979 This restoration project was about restoration of the rammed earth wall (mainly SE side) and reconstruction of missing areas with hollow bricks; the dilapidated NW tower and parts of the SE and SW towers were reconstructed. Mortar with lime and cement was used (see TP4, TP16).

1987 Consolidation of the facade $\left(80 \mathrm{~m}^{2}\right)$ and its coping part $\left(50 \mathrm{~m}^{2}\right)$ of the NE-side tower, total restoration of the SE-side tower and partial restoration of the tower next to the NW portal; these works involved recovery of the traditional process of rammed earth walls. The restoration project required that the walls be made of stones (mamposteria) with courses of hollow bricks, and mortar composed of lime and cement 1:1:8 with a proportion of clay The walls were covered with the same mortar; the bricks underwent further processing (smoothing) so that they were partially uncovered. The interior was filled with cement, maximum size of the stones of $100 \mathrm{~mm}$ and cement layer in the mix (cement H.150). This is what is reported by written documents; however, the real situation is quite different, according to our survey and analysis (seeTP4, TP16).

1988 This are small repairs. The material used for this repair was liquid lime, which seemed to have an excellent performance.

1989- Partial reconstruction of the walls,(internal and external faces), 90 side NE-NW with stone walls (mamposteria) and courses of hollow bricks. The mortar: lime and Portland cement with red riverine sand in a 1:1:8 ratio to obtain a color similar to that of the ancient walls. The external walls were covered with the same mortar, and the bricks were smoothed so that they remained partially uncovered. The interior was filled with $\mathrm{H}$ $150 \mathrm{~cm}$ cement, coarse aggregate, and the upper cover was filled with cement $\mathrm{H}-175 \mathrm{~cm}$, with a coating similar to that of the wall. This is according to written sources; however direct analysis found that these are interventions were very limited, and they partially used techniques similar to 1979 restorations, or strived to imitated the nearby walls stratigraphic units.

1990- The ossuary was demolished ( $\mathrm{SW}$ side), and the facades 2000 damaged by the 1987 rains (NE-NW) were reconstructed by means of the traditional rammed earth technique (see TP2).

2008- The restoration involved the reconstruction of the walls with a 2010 two-sided 'tapia calicostrada' wall and with a crown of mortar made of cement and lime. At the beginning of the works, several points of collapse and a state of diffuse degradation were seen in this part of the walls: vegetation, diffuse humidity. The SW facade, rebuilt with hollow bricks in the second half of the 20th century, was losing its coating and urgently needed repair. In addition, the part previously occupied by the ossuary was seriously deteriorated. Consolidation was achieved by restoring the foundations of the wall, improving drainage, stabilizing the escarpments, reconstructing the demolished portions of the wall, and adequately recomposing its coping part. It was necessary to render the compressed earth resistant by protecting it with the 'calicostrada' of mortar (rammed earth reinforced with milk of lime, poured every time the shuttering boards are repositioned, before the next layer of earth was added) thereby recovering as far as possible its original appearance and characteristics. The wall was capped with a ridge, similar to the present one, of earth mixed with lime, which was chamfered into the walls to maintain the unitary character of the whole. (see TP1).

2015 The intervention was carried out on the SW (24m long, an area of the walls previously occupied by the ossuary, height of the walls about $6 \mathrm{~m}$, average thickness $1.20 \mathrm{~m}$., external walls $144 \mathrm{~m}^{2}$, internal walls $144 \mathrm{~m}^{2}$, coping part $28.80 \mathrm{~m}^{2}$ ). The volume of the walls is due to two layers of brick, which form a chamber filled with building material, perhaps carried out during an earlier consolidation, and which was to be demolished and replaced with rammed earth. During this restoration, some repairs made in previous years with unsuitable material were also removed. In particular, reconstruction of some parts of the wall was carried out by means of the traditional technique of rammed earth with courses of hollow bricks laid 'a soga'; the wooden mold had to be $1.8 \mathrm{~m}$ long, $0.80 \mathrm{~m}$ high and $1.20 \mathrm{~m}$ wide. Moreover, the specifications required the use of Mascarell land and river sand, not excessively yellow and preferably of coarse grain. The coping of the wall was protected by applying layers of cement and lime mortar in ratio of 1:2:6) to which dye was added in order to obtain a color similar to the historical one. (see TP1)

Table 2. Restoration masonry techniques schema. 
5.3.3 16th century mortars and restoration mortars used in the coating of the walls: Written documents contain little information on the type and composition of the mortar used to cover the walls. What we were able to discover about these aspects came from the direct source: thanks to the samplings carried out, it was possible to gain a slightly more precise idea.

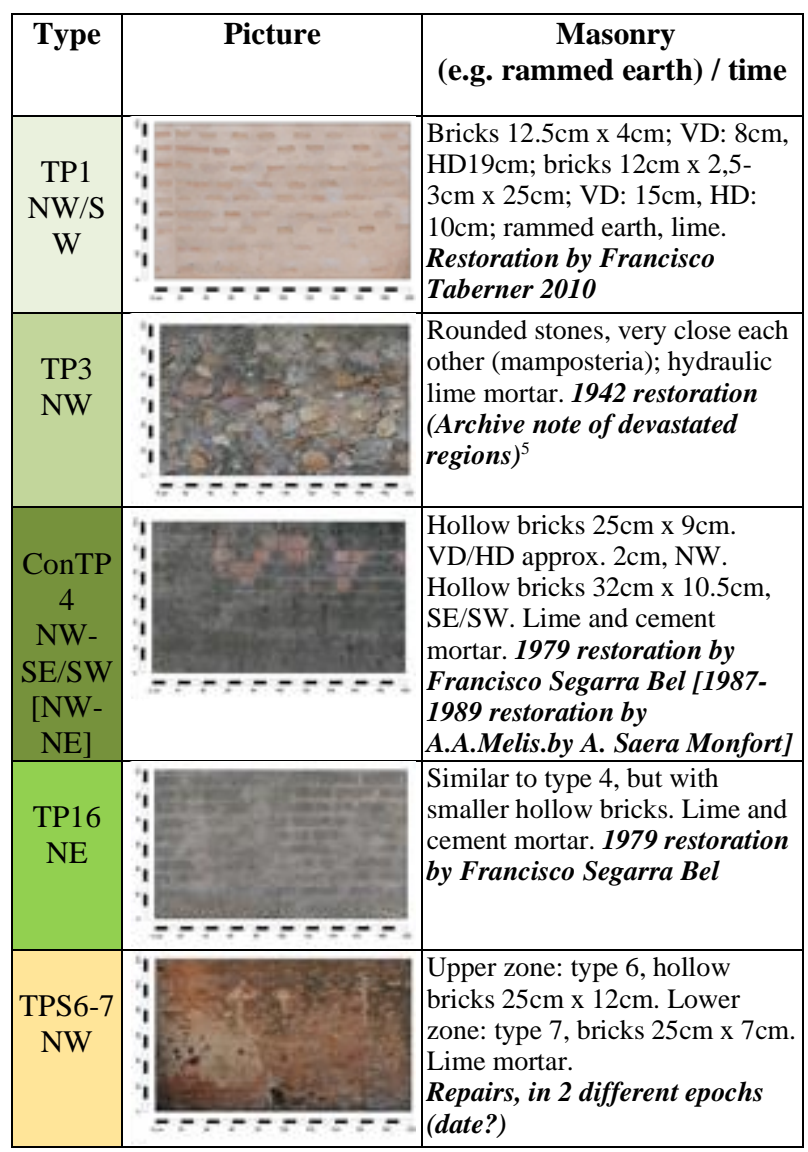

Table 3. Masonry techniques table: the dimensional values are arithmetic average of the values measured on site.

The mortar samples analyzed were taken from all the faces; in accordance with the rules of stratigraphic analysis, samples were taken where differences in appearance or chronology were identified. Very few samples were taken from the upper parts of the walls, both because of accessibility problems and to prevent damaging perfectly intact parts. However, stratigraphic analysis allowed us to overcome this minor drawback, as many nonsampled areas were 'analogous' to sampled areas. This technique provided good information on most wall faces.

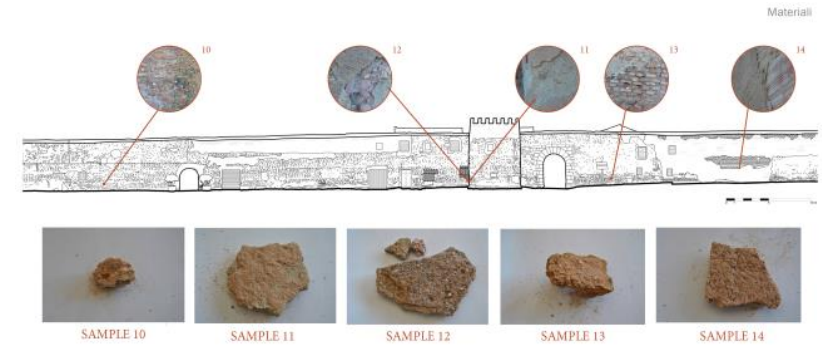

Figure 6. Materials. Different samples, SE façade ${ }^{6}$.

This document has few details, but this 1942 restoration has been understood more from direct analyses.

6 The samples in fig. 6 are characterized by: Binder aerial lime Ss.10, 11, 12, 14; -lime and earth S.13; Aggregate-Sea sand (limestone,
Six types of mortar were identified, which differ in terms of the binder: type A: mortar in which the binder is only earth (sample $13 \mathrm{SE}$ ); type B: mortar in which the binder is earth and airhardening lime (samples $1 \mathrm{SW}, 3 \mathrm{SW}, 4 \mathrm{SW}, 8 \mathrm{SE}, 10 \mathrm{SE}, 11$ SE, $12 \mathrm{SE}, 14 \mathrm{SE}, 15 \mathrm{NW}$ ); type C: mortar in which the binder is air-hardening lime (samples $5 \mathrm{SW}, 7 \mathrm{SW}$ ); type D: mortar in which the binder is earth and hydraulic lime (samples $6 \mathrm{SW}, 9$ $\mathrm{SE}$ ); type E: mortar in which the binder is lime and cement (visible on NW, SE, SW face); type F: mortar in which the binder is lime, cement and earth (visual observation and comparison with documents. NW side, SW side).

From the chronological point of view: the following samples date back to the 16th century: $1 \mathrm{SW}-\mathrm{TPB}, 3 \mathrm{SW}-\mathrm{TPB}, 4 \mathrm{SW}$ TPB, 6SW-TPD(?), 7SW-TPC, 8SE-TPB, 10SE-TPB, 11SETPB, 12SE-TPB, 13SE-TPA, 15NW-TPB. The following samples were identified as interventions between the end of the 19th and the 20th centuries: 6SW-TPD(?), 9SE-TPD, 14SETPB. This sample belonged to 2010 restoration: 5SW-TPC.

From these data it emerges that: A-several interventions were carried out on the coating of the walls over the years; some date back to the original construction, others relate to collateral interventions involving the walls (e.g. the opening/closing of doors or windows in the buildings adjoining the walls), others again concern renovations carried out in the last two centuries. B-in the vast majority of cases, lime-based mortars were used air-hardening lime, hydraulic lime); sometimes dyes were added to match the color of the rammed earth masonry. C-cement is present as a binder only in the most recent interventions The presence of only earth: this was found only in Ss2, 13. In all the other samples, the earth is mixed with lime: in S7, only lime; in Ss6,9, the earth is mixed with hydraulic lime. In some cases, the clast/matrix ratio changes (in some cases low, in others high). The maximum size of the aggregate also changes $(2 \mathrm{~mm}, 3 \mathrm{~mm})$ (Craterre, 1989) and (Casagrande, Di Rocco, Guerinoni, 2019).

\subsection{The state of conservation}

To define the state of conservation, a macroscopic analysis of the walls was carried out. For the lexicon used, we referred to the Recommendations Normall 1/88 and the UNI 11130: 2004 standard Cultural heritage - linear products - terminology of wood degradation. Norm 11182: 2006 cultural heritage. natural and artificial stone materials. Description of the forms of alteration. The SW facade was seen to be the least degraded; $47 \%$ of its surface was in a good state of conservation; however, it presented a high percentage $(8 \%)$ of marked erosion $(8-10$ $\mathrm{cm})$ and black crust concentrations $(10 \%)$. This elevation is the one that was most recently restored. However, as the restored surface is rather small, the 16th century walls still appear in very large areas; it was precisely in one of these areas that these erosion values were recorded; the same applies to the crust. The SE face, on the other hand, was the most degraded. Only $8 \%$ of the surface showed no sign of deterioration; high values $(31 \%)$ of surface deposit were recorded, as were high percentages of 'detachment' and swelling. High values of erosion and craquelure were present; in particular, the phenomenon of craquelure was observed on the portions of coating put in place during the restoration of 1979 . This could be due to a high proportion of the binder in the composition of the mortars. This

quartz, sandstone), Valencia sand, Ss 11,12, 13, 14, Aggregatebrick dust S. 10, Max aggregate size-1mm Ss11,14,-2mm Ss10, $12,-3 \mathrm{~mm} \mathrm{S.13}$; Rounding degree-sub rounded: all 5Ss, Spherical degree-low: all 5Ss, Klasts/matrix ratio-medium S10,-high Ss11, 12, 13, 14, Grain size distribution -poorly classified: all $5 \mathrm{Ss}$, Underburnt lime fragments S.10. 
phenomenon could not generally be interpreted as immediate degradation, but as greater vulnerability of this surface; indeed, these micro-lesions enable water to infiltrate into the wall. In this same prospect, high levels of efflorescence, erosion and disintegration were observed. As expected, the two elevations facing north were those where we observed the greatest amount of degradation phenomena related to humidity (damp spots, biological patina, vegetation, rising damp) are.

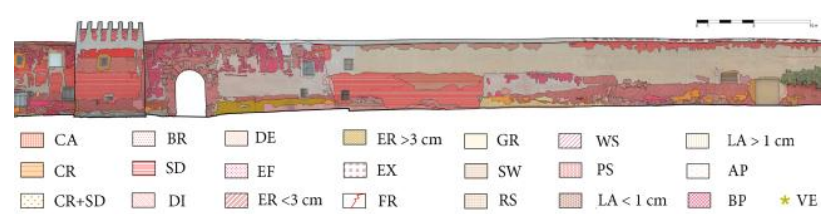

Figure 7. Decay map (extract). Source: Casagrande, Di Rocco, Guerinoni, $2019^{7}$

\section{CONCLUSIONS}

This research highlighted several challenges that earth-made architecture poses: the challenge of understanding and reading the different phases, the challenge of preserving, the challenge of monitoring and steadily maintaining, the challenge of developing and enhancing these particular earth-built architectures. The present research work, which was carried out partly in the field and partly in the archives, yielded a positive response to these challenges. "I am my memory. Without memory my identity dissolves and I disappear" (Eco, 2015). In addition to personal memory, there is a collective memory. An event becomes memorable not only when it matters, but also when it must be remembered. It is, indeed, memorable because it is remembered, because it has overcome oblivion. And memory cannot be isolated; it must be part of a story; thus, the memory can, indeed must, be told. "Only what has been dramatized in language is preserved" (Bachelard, 2008). Our memory is fallible, our memory of past things is imperfect. We should keep alive what we have learned and what we use daily. Therefore, not only do we need a method, but also a container that collects this knowledge and organizes it, allowing its conservation and easy retrieval and, above all, its reuse in creative forms. "Only what has been dramatized in language is preserved"... and in this case the language is the language of the traces on the material, but it is also the language of the digital image .... and the container is the wall of an entire city.

\subsection{Guidelines for restoration and enhancement: a} 'critical evolutionary line' of rammed earth

In the final part of the research, some guidelines for future interventions on the walls of Mascarell were drawn up. These arose from detailed knowledge of the walls, the materials used and their state of conservation. However, critical comparison with walls archaeological analysis was essential. This integrated approach allowed us to identify the interventions and materials that worked best; moreover, where critical and/or vulnerable points were identified, strategies were drawn up in order to remedy these. In accordance with the trends of recent decades, conservative restoration and enhancement were chosen, in order to conserve the memory of all the signs deposited on these walls over time, including during the restorations of the XX-XXI century (Mattone, 2008) and (Galarza Tortajada, 2012) and

$7 \mathrm{CA}=$ Chromatic alteration, $\mathrm{CR}=$ Crazing, $\mathrm{BR}=\mathrm{Black}$ crust, $\mathrm{SD}=$ surface deposit, $\mathrm{DE}=$ Delamination, $\mathrm{EF}=$ Efflorescence, $\mathrm{ER}=$ Erosion, $\mathrm{EX}=$ Exfoliation, layering, $\mathrm{FR}=$ Cracking, $\mathrm{GR}=\mathrm{Graffit}$, $\mathrm{SW}=$ Lime staining, RS=Rust stain, WS=Wet stain, PS=Paint stain, $\mathrm{LA}=$ Lacuna, $\mathrm{AP}=\mathrm{Patina}, \mathrm{BP}=$ Organic Patina, $\mathrm{VE}=$ Vegetation.
(Pittaluga, 2012). The following guidelines were drafted:1) respect for the authenticity of all parts of the walls, including the interventions carried out after the original construction and the restorations; 2) only one case of loss is expected, the elimination of non-compatible materials that could bring deterioration in the short or medium period; 3) preferential use of less invasive cleaning operations; 4) choice of surface consolidation interventions techniques, with preference for inorganic binders; 5) integration of the mortars with compatible material; 6) possibility of reading all future interventions (e.g. the integrations kept slightly below the plane of the surface).

These restoration guidelines follow the principle of preserving as much as possible, both the original materials bat also every transformation sign, every restoration. Why? Because a wider restoration concept is applied, as explained here below.

Repair is a traditional means of fixing what is worn, damaged, or broken; repairing is a way of working that sometimes seems obsolete, anachronistic. To the general public, and to most 'building professionals', earthen architecture belongs to the past. Restoration (i.e. repair) of an earthen architecture is a concept that seems outdated, almost inconceivable. These things are considered irrelevant because progress is supposed to be based on what is new, and what is new is the essence of creativity. "As Elizabeth Spelman has aptly observed, the capacity of professionals to repair things can scarcely be valued in any society whose economy is based on the production and the desire for something new. Repair is at odds with the imperative of a capitalist society" (Matero, 2012). But things are now changing: the global nature of today's challenges, whether physical, social, or cultural, is unprecedented. There is therefore the need to value and conserve the physical, cultural and social environments, bringing together past and present, in order to create new approaches that are suitable to all contexts; this is one of the goals of conservation. In the field of heritage conservation, few material technologies have had the ability and the influence to reconnect the social and environmental processes and concerns of building and conserving; the technique of earth construction links together all these aspects. The lessons of maintenance and repair are intrinsic mandatory traditions of the earthen heritage and they are essential for the people working in this field (Matero, 2012, 17-19). Keeping together past and present, forging sensitive new approaches in every context: these are the targets of conservation. Taking into account what has just been said, we can understand the significance of conserving all traces on the earthen walls of Mascarell (Ginzburg, 2006). This concept is extended to the conservation of the restorations and repairs made over time. In response to the expression 'knowing in order to conserve', we would suggest 'conserving in order to know'; we therefore propose wall stratigraphy techniques as a way to widen and deepen our knowledge: conserving in order to know different restorations, too and also: "In our inevitable subordination to the past, we have freed ourselves at least in the sense that, while remaining condemned to know it exclusively on the basis of its traces, we are nevertheless able to know much more than it wanted to let us know ... it is a great revenge of intelligence on the mere facts" (Bloch 1969, 69).

\section{NOTES AND ACKNOWLEDGMENTS}

This contribution is the result of the collegial activity but pars 1 , $2,3,4,5,5.2,5.3,5.3 .1,5.3 .2,5.3 .3,5.4,6,6.1$ are by D.Pittaluga, 2, 3, 4, 5.1, 6 by G.Pellegri, and 1, 2, 3, 4, 5.3, 5.4 by C.A.Casagrande, A.Di Rocco, S.Guerinoni. This research was financed with PRA2019 (University Research Project), DAD-University of Genoa entitled "Conservazione e restauro: metodiche di analisi e strategie di mantenimento del patrimonio materiale e immateriale", scientific manager D.Pittaluga. 


\section{REFERENCES}

Bachelard, G., 2008: La poetica della rêverie, translation. G.Silvestri Stevan. Dedalo, Bari.

Bloch, M., 1969: Apologia della storia. Einaudi, Torino.

Boato, A., Pittaluga, D., 2000: Building archaeology: a nondestructive archaeology, IPnD, 2000, compact disc, file IDN 35 https://www.ndt.net/article/wcndt00/papers/idn365/idn365.htm.

Caniggia, G., Maffei G.L., 1996: Composizione architettonica e tipologia edilizia. Marsilio, Venezia.

Casagrande, C., Di Rocco, A. Guerinoni S., 2019: Las murallas de Mascarell. La tapia valenciana. Master's Thesis DAD, Università di Genova, sups.: D.Pittaluga, V. Cristini, G. Pellegri, L. Garcia Soriano.

CRATerre, 1989: Traite de construction en terre, Parethese, Marsiglia.

Cristini, V., Martella F., Mileto C., Vegas F., 2015: A parameterization of brick-reinforced rammed earth in Valencian Region (Spain) in Mileto, C., Vegas, F., Garcia, L., Cristini, V. (eds.), 2015, op.cit. 101-106.

Cristini, V., Ruiz Checa J.R., 2009a: Tapia valenciana: caratteristiche di muri in terra cruda rinforzati in mattoni in Meditteranea 2009. Edicom, 1-10.

Cristini, V., Ruiz Checa J.R., 2009b: A historical spanish traditional masonry technique: some features about tapia valenciana as a reinforced rammed earth wall in 11th Canadian Masonry Symposium. CMS Ed. Toronto.

Eco, U., 2015: Noi siamo la memoria, video conference created by Davide Ferrario, Biennale d'Arte di Venezia.

Ferrando Cabona, I., Mannoni, T., Pagella, R., 1989: Cronotipologia in Archeologia Medievale XVII, FI, 647-661.

Font, F., Hidalgo, P., 1990: El tapial, una técnica constructiva milenaria, Colegio de Aparejador de Castellon, Castellon.

Della Torre, S., Pracchi, V., 2006: Saper vedere in Archeologie. Studi in onore di Tiziano Mannoni. Edipuglia, Bari, 453-456.

Galarza Tortajada, M., 1996: The valencian tapia, a little-known construction techniques, Madrid. First National Congress of Cons. History. Ins. Juan de Herrera, CEHOPU.

Galarza Tortajada, M., 2012: Restoration criteria of the Valencian rammed earth walls, in Mileto, C., Vegas, F., Cristini, V. (eds.), 2012, op. cit., 327-332.

Garcia, L., 2015: La restauracion de l'arquitectura de tapia de 1980 a la actualidad a travers de los fondos del Ministerio de Cultura y del Ministerio de Fomento del Gobierno de Espana. $\mathrm{PhD}$ thesis, Universidad Politécnica Valencia, Valencia.

Ginzburg, C., 1998: Occhiacci di legno. Feltrinelli, Milano

Ginzburg, C., 2006: Il filo e le tracce. Feltrinelli, Milano.

Laureano, P., 1995: La piramide rovesciata, il modello dell'oasi per il pianeta Terra, Bollati Boringhieri.
Matero, F.G., 2012: Earthen architecture: Clay feet or a feat of clay, in Mileto C., Vegas F., Cristini V. (eds), op.cit., 17-19.

Martella, F., 2015: La tapia Valenciana, studio y caracterizacion en ejemplos destacados de edificios historicos. Master's Thesis, Universidad Politecnica de Valencia, Valencia.

Mattone, M., 2008: La protezione dell'architettura in terra cruda: ipotesi di intervento, in Terra cruda tra tradizione e innovazione. Edicom, Gorizia, 113-121.

Mileto, C., Vegas F., Garcia Soriano L., Cristini, V., L, Cristini V., 2011-2012: La restauracion de la arquitectura de tapia en la peninsula iberica. Metodologia de catalogacion y analisis de casos. Arché. Publicacion del Instituto Universitario de Restauracion del Patrimonio de la UPV. N.6,7.

Mileto, C., Vegas, F., Cristini, V. (eds.), 2012: Rammed earth Conservation. CRC press, Taylor\&Francis group, London UK.

Mileto, C., Vegas, F., Garcia, L., Cristini, V. (eds.), 2015: Earthen Architecture. CRC Taylor\&Francis group, London UK.

Moneo, R., 1978: On topology in Oppositions (13).

Muratori, S., 1984: Saverio Muratori, architetto (1910-1973): il pensiero e l'opera. Alinea, Firenze.

Musso, S.F., 2015: Materia/Cultura Materiale, ANANKE 75, 34

Pittaluga, D., 2009a: Questioni di Archeologia dell'Architettura e Restauro. ECIG, Genova.

Pittaluga, D., 2009b: La mensiocronologia dei mattoni. ECIG, Genova.

Pittaluga, D., 2012: Earth and bricks architecture: For a conservation of stratigraphical traces in Mileto C., Vegas F., Cristini V. (eds), op.cit., 699-704.

Pittaluga, D., Pagella, R., 2015: First considerations for an adobes mensio-chronology in Mileto, C., Vegas, F., Garcia, L., Cristini, V. (eds.), op.cit., 287-292.

Pittaluga, D., Fratini, F. (eds.), 2019: Conservation nd promotion of architectural and landscape heritage of the Mediterranean coastal sites. F.Angeli, Open access Milano, http://ojs.francoangeli.it/_omp/index.php/oa/catalog/book/437

Quatremère de Quincy,A., rp.1985: Tipo, tipologia in Dizionario storico d'architettura. Marsilio, Venezia.

Rauch, M., Kapfinger, O., Sauer, M., 2015: Construction e Design with Rammed Earth. Detail; (Ia ed. Rauch, M., Kapfinger, O., Rammed Earth. Birkhauser, 2001).

Rogers E.N., 1964: Metodo e tipologia, in Casabella Continuità, n. 291, settembre 1964, p. 1.

Scudo, G., Bonati N. (eds.), 1994: Architettura in terra, memoria e innovazione. Città Studi ed., Milano.

Taberner Pastor, F., 2012: Valencian tapia in the walled city of Mascarell (Castellon, Spain) in Mileto C., Vegas F., Cristini V. (eds), op. cit., 237-241.

Torsello, P.B., 2006: Figure di pietra. Marsilio, Venezia. 